\title{
EFICIENCIA DE USO DE LOS RECURSOS, PRODUCTIVIDAD Y PRODUCCIÓN EN MAÍZ SEGÚN DIFERENTES CULTIVOS ANTECESORES
}

\author{
Pietrobón, M. ${ }^{1}$; IMVINKELRIED, H. O. ${ }^{1}$; \\ Dellaferrera, I. M..$^{1,2} \&$ Montenegro, A. J. ${ }^{3}$
}

\begin{abstract}
RESUMEN
La producción de materia seca y grano depende de la habilidad de los cultivos en capturar los recursos. La intensificación sustentable involucra un incremento en la productividad del sistema a través de un uso más intenso de los mismos. Este trabajo pretendió aportar resultados regionales en cuanto a alternativas de secuencias agrícolas sobre eficiencia de uso de los recursos y productividad y producción del maíz. El ensayo se realizó durante 2014 y 2015 en Esperanza (Santa Fe). Se implantaron tres cultivos invernales y luego maíz de segunda con dos niveles de fertilización nitrogenada. La fertilización nitrogenada mejoró la materia seca total, el rendimiento y la eficiencia de uso de agua; pero, provocó una caída en la eficiencia de uso de N. La falta de respuesta del maíz con respecto a los cultivos antecesores fue atribuida a las características favorables del año y a la escasa productividad de la vicia.
\end{abstract}

Palabras claves: Zea mays L., eficiencia de uso de nitrógeno, eficiencia de uso de agua, rendimiento.

\begin{abstract}
Efficient use of resources, productivity and corn production by different cultures ancestors.

Production of dry matter and grain depends on the ability of the crops to harvest the resource. Sustainable intensification involves increased system productivity through a more intense use thereof. This work aimed to provide regional results in terms of agricultural alternative sequences on resource use efficiency and productivity and production of corn. The test was conducted during 2014 and 2015 in Esperanza (Santa Fe). Three winter crops implanted and then second maize with two levels of nitrogen fertilization. Nitrogen fertilization improved total dry matter, yield and water use efficiency; but caused a decline in nitrogen use efficiency. The lack of response of maize with respect to ancestors crops was it attributed to favorable characteristics of the year and low productivity of vetch.

Key words: Zea mays L., nitrogen use efficiency, water use efficiency, yield.
\end{abstract}

1.- Facultad de Ciencias Agrarias (UNL). Kreder 2805. (3080) Esperanza, provincia de Santa Fe.

Email: mpietrobon@fca.unl.edu.ar

2.- CONICET

3.- Cientibecario FCA - UNL

Manuscrito recibido el 14 de abril de 2016 y aceptado para su publicación el 10 de mayo de 2016. 